\section{Fullerenes from coal}

SIR - Given their many potential applications $^{1-4}$, it is likely that $\mathrm{C}_{60}$ and $\mathrm{C}_{70}$ fullerenes ${ }^{5}$ will be required in macroscopic quantities. So far such quantities have been produced from the heating or arcing of graphite ${ }^{6,7}$. But graphite is already a value-added carbon, costing $\$ 1,000-5,000$ per tonne. Previously we have detected $\mathrm{C}_{60}$ and higher fullerenes during laser ablation of a brown coal in an ion cyclotron mass spectrometer ${ }^{8-10}$. We have now prepared macroscopic quantities of fullerenes from coalderived coke, a relatively cheap and abundant source.

A coking coal from the Goonyella seam, Australia, was demineralized according to published procedures ${ }^{11}$. Three fractions of this coal with mineral matter contents of $0.7,2.9$ and 7.9 per cent, respectively were obtained. Each coal fraction was finely ground and heated in argon for 24 hours at $395{ }^{\circ} \mathrm{C}$ to form a rod of approximately $18 \mathrm{~mm}$ (diameter) $\times 45 \mathrm{~mm}$ (length). The rod was converted to coke by further heating at $1,200{ }^{\circ} \mathrm{C}$ in argon for $5 \mathrm{~h}$. The final coke rod has an electrical resistance of between 1.5 and 3 ohms along its length. In a typical experiment, two coke rods were subjected to electrical arcing at 24 $\mathrm{V}$ and an a.c. current of 105-110 A, in a manner similar to that of Haufler et al. ${ }^{6}$, under a 250-torr helium atmosphere. The soot collected was Soxhlet-extracted with toluene. The yield data of the toluene-soluble product and the duration of arcing for the different coal fractions are listed in the table. Infrared spectroscopy of the toluene-extracted product reveals absorption peaks characteristic of $\mathrm{C}_{60}$ and $\mathrm{C}_{70}$ fullerenes in ratios of about $10: 1$, similar to those reported with graphite as the source ${ }^{7}$. These ratios have been confirmed by ${ }^{13} \mathrm{C}$ NMR. The $\mathrm{C}_{60}$ and $\mathrm{C}_{70}$ fullerenes were separated by chromatographic techniques ${ }^{12}$.

The presence of mineral matter in the coal does not inhibit fullerene formation

1. Stoddart, J. F. Angew Chem. Int. Ed. Engl. 30, 70-71 (1991).

2. Haddon, R. C. et al Nature 350, 320-322 (1991).

3. Hebard, A. F. et al. Nature 351,600-601 1991)

4. Burch, W. M., Sullivan, P.J. \& McLaren, C.J. NuCl. Medical Commun. 7, 865-871 (1986).

5. Kroto, H. W., Heath, J. R. O'Brien, S. C., Curl, R. F. \& Smalley, R. E. Nature 318, 162-163 (1985).

6. Haufler, R. E. et al. J. Phys. Chem. 94, 8630-8636 (1990).

7. Kratschmer, W., Lamb, L. D., Fostiropoulos, K. \& Huffman, D. R. Nature 347, 354-358 (1990).

8. Greenwood, P. F. et al. Am. Chem. Soc. Div. Fuel Chem. Prepr. 34, 773-779 (1989).

9. Greenwood, P. F. et al. Fuel 69, 257-260 (1990).

10. Greenwood, P. F., Strachan, M. G., Willet, G. D. \& Wilson, M. A. Org. Mass Spec. 25, 353-362 (1990).

11. Waugh, A. B. \& Bowling, K. McG. Fuel Proc. Technol. 9, $217-233$ (1984).

12. Bethune, D. S. et al. Chem. Phys. Lett. 179, 181-186 (1991).

13. Brooks, J. D. \& Taylor, G. H. in Chemistry and Physics of Carbon (ed. Walker, P. H. Jr) 282 (Dekker, New York, 1968).

† From demineralized coal.

NA not applicable. from coke, although the amount of mineral matter does seem to have an effect on the total yield. At a level of 2.9 per cent mineral matter, an optimal yield of 8.6 per cent was obtained, comparing favourably with the yield of 9.3 per cent obtained from graphite under identical conditions. Fullerenes were also produced from coke derived from Coalcliff middlings coal ( 3 per cent yield with a d.c. current and 2 per cent with a.c.) and Newvale vitrinite (6 per cent yield d.c.). Thus it seems likely that other conductive coke materials will be able to act as a source of fullerenes. The use of a d.c. current rather than a.c. seems to increase markedly the yield of fullerenes from both graphite and coal. This is probably because of the more stable arc and the relatively higher mean power when d.c. is used. X-ray diffraction of the coke rods shows very little evidence of graphitization: Coking occurs readily at $1,200^{\circ} \mathrm{C}$, but graphitization does not occur fully until $2,500^{\circ} \mathrm{C}$ (ref. 13). With the present cost of coke at about $\$ 500$ per tonne, its use as an industrial source of fullerenes would greatly improve the economics of production.

LOUIS S. K. PANG

ANTHONY M. VASSALLO

MICHAEL A. WILSON

\section{CSIRO Division of Coal and}

Energy Technology.

PO Box 136, North Ryde,

New South Wales 2113,

Australia

\begin{tabular}{|c|c|c|c|c|c|c|c|}
\hline \multicolumn{8}{|c|}{ EXPERIMENTAL CONDITIONS AND YIELDS OF CRUDE FULLERENES FROM COKE AND GRAPHITE } \\
\hline $\begin{array}{l}\text { Source } \\
\text { carbon }\end{array}$ & $\begin{array}{l}\text { Coal } \\
\text { mineral } \\
\text { matter } \\
\text { content } \\
\text { (wt \%) }\end{array}$ & $\begin{array}{c}\text { Current } \\
\text { type }\end{array}$ & $\begin{array}{l}\text { Duration } \\
\text { of arcing } \\
\text { (h) }\end{array}$ & (g) & $\begin{array}{l}\text { eld } \\
\left(\mathrm{gh}^{-1}\right)\end{array}$ & $\begin{array}{l}\text { Toluene } \\
\text { solubles } \\
\text { (g) }\end{array}$ & $\begin{array}{l}\text { Percentage } \\
\text { yield } \\
\text { from } \\
\text { soot } \\
\text { (wt \%) }\end{array}$ \\
\hline $\begin{array}{l}\text { Coke } \\
\text { (Goonyella) }\end{array}$ & $7.9 *$ & a.c. & 4 & 3.20 & 0.80 & 0.18 & 5.6 \\
\hline $\begin{array}{l}\text { Coke } \\
\text { (Goonyella) }\end{array}$ & $2.9+$ & a.c. & 4 & 1.74 & 0.435 & 0.15 & 8.6 \\
\hline $\begin{array}{l}\text { Coke } \\
\text { (Goonyella) }\end{array}$ & $0.7 \dagger$ & a.c. & 1 & 1.09 & 1.09 & 0.025 & 2.3 \\
\hline Graphite & NA & a.c. & 4 & 1.07 & 0.28 & 0.100 & 9.3 \\
\hline Graphite & NA & d.c. & 2 & 1.91 & 0.96 & 0.31 & 16.2 \\
\hline
\end{tabular}

* From as-received coal, air dried and contains 1.3 per cent moisture.

\section{Penguins shed stomach linings}

SIR - As a member of the 1990-91 Dutch Antarctic expedition, I observed chinstrap penguins (Pygoscelis antarctica) vomiting their stomach linings. On closer inspection, the colony was strewn with shed linings, and a penguin regurgitating its stomach wall on its way to the sea to feed was a common sight. This habit, which has never been reported, is not seen in other Pygoscelis species, despite almost identical food and feeding habits.

I could think of two reasons for my observation. First, the stomach wall might need adjustment when birds have to feed chicks. The phenomenon would then be seen only near hatching time, and might therefore have remained undetected previously. By dye-marking birds, I established that regurgitation happens in birds with chicks of all ages, but also in non-breeders, throughout the chick-rearing season.

Second, birds could accumulate fluoride in their stomach walls, avoiding excessive fluoride uptake by regular shedding. Antarctic krill contains toxic levels of flouride, concentrated in the exoskeleton to up to 3,000 p.p.m. dry weight (dwt). Many antarctic animals feed on krill, and various authors ${ }^{2-4}$ have reported on fluoride levels and fluoride turnover in antarctic animals. Penguins and seals accumulate fluoride in their bones up to 10,000 p.p.m. dwt, and keep levels in their soft tissues below 10 p.p.m. dwt. Some chinstrap stomach walls were analysed by Boris Culik, and appear to contain up to 330 p.p.m. dwt, the highest fluoride levels ever found in soft tissue. In $P$. adeline stomach walls, which are not regurgitated, Culik found only slightly raised levels, up to about 20 p.p.m. dwt, which he attributed to contamination with krill fragments. Despite this difference, daily shedding of stomach walls with concentrations around 300 p.p.m. dwt would remove only an insignificant part (about 0.1 per cent) of the daily amount of fluoride

1. Adelung, D., Buchholz, F., Culik, B. \& Keck, A. Pola Biol. 7, 43-50 (1987).

Schneppenheim, R. Meeresfonchung 28, 179-182 (1980).

3. Culik, B. Comp. Biochem. Physiol. 88A, 229-233 (1987)

4. Culik, B. Polar Biol. 7, 179-187 (1987). 